\title{
PEMANFAATAN MICROSOFT EXCEL DALAM MEMBANTU PENYUSUNAN LAPORAN KEUANGAN DI TPQ AN-NAJAH TIRTO PEKALONGAN
}

\author{
Shohabatussa'adah ${ }^{1)}$, Muasomah ${ }^{2)}$ \\ 1) Akuntansi Syariah, Fakultas Ekonomi dan Bisnis Islam, IAIN Pekalongan,e-mail : shohabahtirto16@gmail.com \\ 2) Pendidikan Bahasa Arab, Fakultas Tarbiyah dan Ilmu Keguruan, IAIN Pekalongan, e-mail : \\ muasomah@iainpekalongan.ac.id
}

\begin{abstract}
Abstrak
Kemajuan IPTEK menuntut sebuah kewajiban pada penguasaan ilmu di bidang tekonologi informasi untuk menghadapi era globalisasi ini. Artikel ini membahas mengenai pemanfaatan excel dalam membantu penyusunan laporan keuangan. Untuk menunjang kelancaran proses pembelajaran di lembaga pendidikan dalam hal ini di Taman Pendidikan Al-Qur'an (TPQ) diperlukan suatu bagian yang mendukung kegiatan tersebut yaitu tata usaha. Tata usaha lembaga pendidikan merupakan ujung tombak pelayanan jasa pendidikan suatu lembaga yang secara langsung menangani pelayanan di dalam internal maupun eksternal. Akan tetapi tenaga tata usaha masih belum cukup baik melayani administrasi ketatausahaan karena beberapa hal yang menjadi kendala.Tidak terkecuali bagi bidang pendidikan. Melalui Microsoft Excel, laporan keuangan dapat disusun secara sederhana dengan siklus yang lebih pendek yaitu dari penyusunan jurnal menjadi laporan keuangan sederhana. Adapun tujuan dari tulisan ini adalah untuk memberikan pelatihan mengenai proses penyusunan laporan keuangan melalui Microsoft Excel agar mengefisiensikan kinerja tata usaha. Metode yang digunakan dalam pengabdian ini meliputi ceramah, tanya jawab dan simulasi. Adapun hasil dari pengabdian ini menunjukkan bahwa pelatihan ini memberikan pengetahuan khususnya bagi tata usaha mengenai proses akuntansi sederhana dengan memanfaatkan excel seperti perekapan, pengelompokan akun, penjurnalan, posting ke buku besar bahkan sampai pada pembuatan laporan keuangan yang dipraktekan secara langsung.
\end{abstract}

Kata Kunci: kemajuan IPTEK, Microsoft Excel, tata usaha, pendidikan, laporan keuangan

\begin{abstract}
Science and Technology Progress requires an obligation to mastery of science in the field of information technology to face this era of globalization. This article discusses the utilization of Excel in assisting the preparation of financial statements. To support the smoothness of the learning process in educational institutions in this case in the Al-Qur'an Education Park (TPQ), a part that supports the activity, namely administration. Administration of educational institutions is the spearhead of the education services of an institution that directly handles services within the internal and external. However, administration workers are still not quite good at serving the administration of work and some things become obstacles. Not except for the education sector. Through Microsoft Excel, financial statements can be arranged simply with a shorter cycle, namely from the drafting of journals into a simple financial report. The purpose of this paper is to provide training on the process of preparing financial statements through Microsoft Excel to streamline the performance of administration. The method used in this service includes lectures, question and answer and simulation. The results of this service show that this training provides knowledge especially for administration regarding simple accounting processes by utilizing excel such as recipates, grouping accounts, transvuncurements, posts to ledgers even to the manufacture of financial reports directly practiced.
\end{abstract}

Keywords: Progress of Science and Technology, Microsoft Excel, Administration, Education, Financial Statements 


\section{PENDAHULUAN}

Era digital yang ditandai dengan perkembangan iptek yang semakin canggih telah membawa perubahan besar terhadap berbagai aspek kehidupan manusia menjadi lebih mudah. Masyarakat Indonesia pun kini memiliki gaya hidup baru yang tidak bisa dilepaskan dari yang namanya perangkat elektronik dalam kehidupan sehari-hari. Berbagai informasi kini dapat diakses dengan mudah sehingga masyarakat senantiasa update dan berbagi informasi setiap saat dengan frekuensi tinggi.

Kemajuan teknologi yang terus berkembang sampai saat ini seiring dengan kebutuhan lembaga dalam melakukan efisiensi yang mulai menerapkan seluruh kegiatan dilakukan dengan menggunakan sistem secara komputerisasi. Kebutuhan tersebut mencakup pada kebutuhan dalam menyusun suatu laporan keuangan dimana laporan keuangan mulai disusun dengan menggunakan sistem teknologi sehingga pencatatan akuntansi didalam suatu lembaga dilakukan dengan menggunakan komputer (Triandi and Agustin, 2016). Hal tersebut menjadikan lebih mudah dan cepat sehingga dapat meminimalisir kesalahan dalam penyusunan laporan keuangan.

Kunci pembangunan masa mendatang bagi bangsa Indonesia adalah pendidikan. Sebab dengan pendidikan diharapkan setiap individu mengetahui keberadaannya dan mampu berpartisipasi dalam gerak pembangunan. Dengan pesatnya perkembangan dunia di era globalisasi pengetahuan maka pendidikan juga harus terus menerus dikembangkan seiring dengan perkembangan zaman. Setiap lembaga pendidikan sangat memerlukan ketatausahaan. Karena tata usaha merupakan bagian penting demi menunjang kelancaran dan terpenuhinya tujuan lembaga pendidikan.

Tata usaha adalah kegiatan yang dilakukan meliputi membantu proses belajar mengajar, urusan kesiswaaan, kepegawaian, peralatan, urusan infrastruktur sekolah, keuangan dan hubungan masyarakat (Nofiani, 2019). Peran tata usaha salah satunya adalah menyediakan informasi bagi kepalanya, dengan informasi tersebut maka seorang kepala dalam mempertimbangkan keputusannya akan lebih cepat. Dengan adanya tata usaha pula maka kelancaran pekerjaan dan kemungkinan kesalahan dalam pekerjaan menjadi kecil.

Dunia pendidikan merupakan sebuah bagian yang tidak bisa terpisahkan dari kehidupan bermasyarakat pada umumnya. Pendidikan memang selalu identik dengan proses belajar mengajar karena hal tersebut memang merupakan kegiatan utama dalam dunia pendidikan. Namun di samping kegiatan belajar mengajar ada banyak hal yang mendukung untuk berlangsungnya kegiatan belajar mengajar tersebut. Salah satunya adalah kegiatan pada bagian administrasi. Bagian administrasi merupakan bagian yang sehari-harinya melakukan kegiatan rutin menulis, menghitung serta mengelola data pada suatu instansi pendidikan (Hariani and Sihotang, 2020).

TPQ (Taman Pendidikan Al-Quran) merupakan suatu lembaga yang menyelenggarakan pendidikan non formal berbasis keagamaan yang bertujuan untuk memberikan pengajaran membaca Al-Quran sejak usia dini dan memahami dasar-dasar agama Islam untuk anak usia TK, SD/MI bahkan tingkatan yang lebih tinggi. TPQ setara dengan RA atau TK dimana kurikulumnya ditekankan pada pemberian dasar-dasar membaca Al-Quran dan membantu tumbuh kembang rohani anak supaya memiliki kesiapan dalam memasuki jenjang pendidikan yang lebih tinggi. TPQ bertujuan menyiapkan terbentuknya generasi Qur'ani, yaitu generasi yang memiliki komitmen terhadap $\mathrm{Al}$ Qur'an sebagai sumber perilaku, pijakan hidup dan rujukan segala urusannya. Hal ini ditandai dengan kecintaan yang mendalam terhadap Al Qur'an, mampu dan rajin membacanya, terus menerus mempelajari isi kandungannya, dan memiliki kemauan yang kuat untuk mengamalkannya dalam kehidupan sehari-hari.

$$
\text { Kegiatan Kuliah Kerja Nyata (KKN) }
$$
merupakan bentuk pendidikan dengan cara memberikan pengalaman belajar kepada mahasiswa untuk hidup di tengah masyarakat yang secara langsung mengidentifikasi dan menangani permasalahan masyarakat. KKN juga merupakan program yang mengintegrasikan secara menyeluruh 
ilmu yang dimiliki ke dalam wujud nyata pengabdian masyarakat yang memadukan pelaksanaan Tri Dharma Perguruan Tinggi sebagai wahana penerapan dan pengembangan ilmu yang telah didapatkan dan diaplikasikan kepada masyarakat.

KKN-DR adalah respons secara akademik terhadap problem sosial yang sedang terjadi di tengah-tengah masyarakat. Pelaksanaan KKN-DR ini bersifat mandiri dan bertempat di domisili atau tempat tinggal saat ini mahasiswa masing-masing. Kelurahan Tirto adalah domisili peneliti saat ini untuk tempat KKN-DR. Kelurahan Tirto adalah salah satu kelurahan yang ada di wilayah Pekalongan bagian barat. Kelurahan Tirto sangat banyak sekali potensi yang dapat digali dalam berbagai aspek tinggal bagaimana kita mengelola potensi tersebut agar membuahkan hasil nyata. Oleh karena itu, sebagai salah satu bentuk Kuliah Kerja Nyata Mandiri dalam rangka mengabdi untuk masyarakat, dalam hal ini peneliti akan mencoba melakukan pemberdayaan masyarakat melalui ekonomi.

Berdasarkan latar belakang tersebut, maka peneliti terjalin kerjasama dengan TPQ An-Najah sebagai upaya pengabdian kepada masyarakat untuk membekali soft skill berupa pelatihan excel dalam membantu proses penyusunan laporan keuangan. Melalui pelatihan ini diharapkan akan diperoleh pengetahuan dan ketrampilan yang dibutuhkan untuk pekerjaan sehingga dapat didayagunakan secara optimal melalui terciptanya suatu kondisi yang memenuhi semboyan The Right Man On The Right Job At The Right Time yaitu tepat orang, tepat pekerjaan dan tepat waktu yang semuanya dapat mendukung manajemen kinerja organisasi (Niati et al., 2019).

\section{METODOLOGI PENGABDIAN}

Jenis kegiatan pengabdian pada masyarakat ini adalah berbentuk pelatihan dan praktik langsung. Adapun subjek dari pelatihan ini adalah tata usaha dari TPQ An-Najah. Dalam pelaksanaanya tata usaha TPQ An-Najah dalam hal ini Bu Tianah diberikan modul pelatihan ms excel dalam bentuk softfile dengan pemateri peserta KKN. Pengabdian dalam hal ini adalah KKN dilaksanakan selama lima hari dengan waktu dan tanggal yang kondisional. Pelatihan ini dilaksanakan di rumah tata usaha TPQ An-Najah yang beralamatkan di Jalan KH. Ahmad Dahlan Gg 16. Alasan pengambilan lokasi tersebut karena ketika di TPQ An-Najah Bu Tianah melaksanakan tugas dan kewajibannya sebagai tata usaha. Sedangkan materinya meliputi pengelompokkan akun, pembuatan jurnal, posting ke buku besar dan pembuatan laporan keuaangan. Adapun jadwal pelaksanan dan rincian materi dapat dilihat pada Tabel 1.

Tabel 1 Jadwal Pelaksanaan dan Materi Pelatihan

\begin{tabular}{|c|c|c|}
\hline \multirow[t]{2}{*}{ No } & \multirow[t]{2}{*}{ Keterangan } & Pertemuan \\
\hline & & $\begin{array}{lllll}1 & 2 & 3 & 4 & 5\end{array}$ \\
\hline 1. & $\begin{array}{lll}\text { Pengambilan } & \text { data } & \text { dan } \\
\text { wawancara } 1 & & \end{array}$ & \\
\hline 2. & Wawancara 2 & \\
\hline 3. & $\begin{array}{l}\text { Pelatihan rekapitulasi } \\
\text { syahriyah per cawu }\end{array}$ & \\
\hline 4. & $\begin{array}{l}\text { Pelatihan pengelompokan } \\
\text { akun, penjurnalan dan } \\
\text { posting buku besar }\end{array}$ & \\
\hline 5. & $\begin{array}{l}\text { Pelatihan penyusunan } \\
\text { laporan keuangan }\end{array}$ & \\
\hline
\end{tabular}

Adapun metode yang digunakan dalam pelatihan ini (Yudha et al., 2017) adalah:

1. Metode Ceramah

Metode ini digunakan untuk memberikan penjelasan tentang proses penyusunan laporan keuangan TPQ dengan menggunakan program Microsoft Excel.

2. Metode Tanya Jawab

Metode ini merupakan parameter yang digunakan untuk mengetahui pemahaman atas materi yang disampaikan. Proses tanya jawab berupaya untuk menemukan permasalahan di lapangan mengenai proses penyusunan laporan keuangan TPQ serta solusi yang dapat dilakukan dalam menyelesaikan permasalahan tersebut.

3. Metode Simulasi

Metode ini bertujuan untuk memberikan pengalaman secara langsung proses penyusunan laporan keuangan TPQ. Dengan 
demikian peserta dapat memahami dengan lebih baik dari mulai mengelola transaksi hingga penyusunan laporan keuangan. Simulasi ini dilakukan dengan menggunakan software Microsoft Excel 2007.

Sarana dan prasarana yang diperlukan dalam pelaksanaan kegiatan pelatihan analisis data penelitian ini:
a. Laptop / Komputer
b. Modul materi pelatihan

\section{PELAKSANAAN KEGIATAN}

Pengabdian ini dilaksanakan selama lima hari dari tanggal 1 sampai 5 November 2020. Pekalongan terkenal Pekalongan dikenal sebagai kota santri. Tidak jarang apabila di Pekalongan terdapat banyak Taman Pendidikan Al-Quran. Taman Pendidikan Al--Quran adalah lembaga pendidikan non formal berbasis keagamaan bagi anak usia dini. Salah satu TPQ yang ada di Kota Pekalongan adalah TPQ An-Najah. TPQ An-Najah beralamatkan di Jl KH Ahmad Dahlan Gg 16 No 12 Tirto Pekalongan Barat yang dikepalai oleh Bapak Sonhaji. TPQ ini berdiri pada tanggal 1 Oktober 2002 dimana dulunya TPQ An-Najah adalah bagian dari TPQ Darussalam Samborejo Tirto.

Tenaga pendidik di TPQ An-Najah untuk tingkat TPQ terdapat 13 guru sudah termasuk Kepala TPQ yang merangkap mengajar dan 6 guru untuk tingkat Madin (Madrasah Diniyah) serta 1 tenaga tata usaha. TPQ An-Najah berada di bawah naungan Yayasan An-Najah Ali Maliki supaya mendapat payung hukum yang lebih kuat dengan Akta Notaris Risbert, SH.MH Nomor: 04 Tanggal 08 Juni 2015 SK Menteri Hukum dan HAM.RI Nomor AHU-0008193.AH.01.04 Tahun 2015. Menjadi bagian dari yayasan adalah tuntutan Undang-Undang untuk lembaga pendidikan agar memiliki badan hukum tersendiri. Semenjak berpayung hukum yayasan hubungan kepada semua pihak luar menjadi lebih leluasa dan apabila ada kerjasama dalam hal bantuan baik itu berupa materi maupun dana sudah memenuhi syarat untuk masuk kategori lembaga pendidikan yang mendapat bantuan. Tidak hanya itu, payung hukum yayasan ini menjadikan TPQ An-Najah dapat bekerjasama dengab yayasan lain pula.
Kerjasama dalam bentuk bantuan ini membuahkan hasil yang nyata, TPQ An-Najah dapat melakukan pembangunan dua kali gedung berlantai 2 sebanyak dua unit, halaman TPQ yang lebih tertata dan TPQ menjadi memiliki sanitasi atau toilet tersendiri. Untuk perencaaan kedepan TPQ An-Najah hendak melakukan pembangunan kembali untuk ruang TU (Tata Usaha) dan Kepala Sekolah. Sebab tidak dapat dipungkiri bahwa TPQ An-Najah meski memiliki ruang belajar yang sudah berlantaikan dua TPQ An-Najah masih kekurangan ruang belajar alhasil Mushola menjadi alternatif kelas tambahan ketika jumlah santri mengalami overload.

Sumber-sumber pendanaan untuk keberlangsungan TPQ An-Najah meliputi iuran syahriyah santri, bantuan yang tidak mengikat, bantuan dari Pemkot Pekalongan dan Pemprov Jateng bantuan insentif untuk guru dan bantuan secara berkala yang bersifat fisik daru Pemprov, Pemkot dan Aghniya. Sumber pendanaan ini tidak serta merta diabaikan begitu saja akan tetapi wajib dilaporkan pertanggungjawabannya kepada pihak terkait. Dalam menyusun laporan pertanggungjawaban ini tidak lepas dari tenaga tata usaha. Tata usaha bertugas sebagai penyelenggara kegiatan administrasi yakni urusan tulis menulis termasuk hal keuangan dan sebagainya.

Berdasarkan hasil wawancara dengan tenaga tata usaha di TPQ An-Najah didapatkan informasi bahwa tata usaha di TPQ An-Najah bertanggungjawab mengurusi syahriyah TPQ, membuat laporan dan dan tahunan serta kegiatan administrasi lainnya seperti memesan lembar soal ujian santri, mencatat pengambilan syahadah wisuda, pembelian kitab baru dan administrasi lainnya. Bu Tianah selaku Tata Usaha di TPQ AnNajah sekarang ini bertugas menggantikan Tata Usaha lama yakni Bu Feti dari tahun 2018 sampai sekarang. Tidak mudah dalam mengemban tugas sebagai Tata Usaha baru apalagi $\mathrm{Bu}$ Tianah notabenenya adalah berlatarbelakang pendidikan SMA jurusan IPA sehingga merasa sedikit kesulitan karena bukan bekerja di bidangnya. Selain itu, beliau merasa keteteran karena sendirian dan ketika pergantian tata usaha baru dari tata usaha lama tidak diajari urusan ketatausahaan di TPQ. Tidak hanya itu, penyusunan laporan keuangan di TPQ An-Najah 
masih sangat manual dengan berbekal buku besar. Setelah wawancara dengan Kepala TPQ penyusunan laporan keuangan ini sebenarnya sudah mau menggunakan komputer akan tetapi fasilitas komputer yang disediakan belum memadai dan komputer sering mati. Alhasil perihal laporan keuangan masih manual.

\section{HASIL DAN PEMBAHASAN}

\section{Pelatihan Penerapan Akuntansi Berbasis Komputer}

Kegiatan pelatihan ini dilaksanakan selama lima hari yang dikhususkan kepada tenaga tata usaha TPQ An-Najah yang baru berjumlah satu yang berlokasikan di rumah tata usaha TPQ AnNajah. Sebelum pelatihan dilaksanakan ada sesi wawancara kepada tata usaha dan kepala TPQ terkait hal-hal apa saja yang menjadi kendala dalam penyusunan laporan keuangan dan yang setara dengan itu.

1. Rekapulasi syahriyah per cawu

TPQ An-Najah menggunakan periode cawu (catur wulan) dimana cawu adalah pembagian sistem pembelajaran dengan evaluasi belajar dalam satu tahun dibagi menjadi menjadi 3 bagian atau sebanyak 4 bulan satu kali evaluasi. Dalam hal ini cawu 1 digunakan sebagai objek yakni dari bulan Juli September 2020.

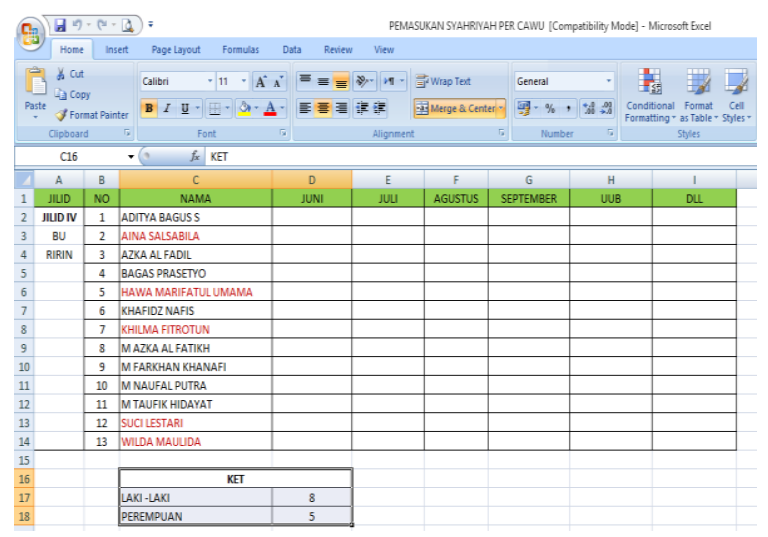

Gambar 1 Pemindahan rekapitulasi syahriyah per cawu dari buku besar ke Microsoft Excel

2. Pengelompokan akun

Akun adalah formulir khusus yang digunakan untuk mencatat dan menggolongkan transaksi-transaksi sejenis.
Kumpulan akun yang saling berhubungan dan merupakan satu kesatuan disebut buku besar. Bentuk akun sederhana terdiri dari tiga bagian yaitu Nama akun, Tempat untuk mencatat penambahan, dan tempat untuk mencatat pengurangan. Pengelompokan akun dilakukan di TPQ An-Najah hanya sebatas catatan kas masuk-keluar sederhana.

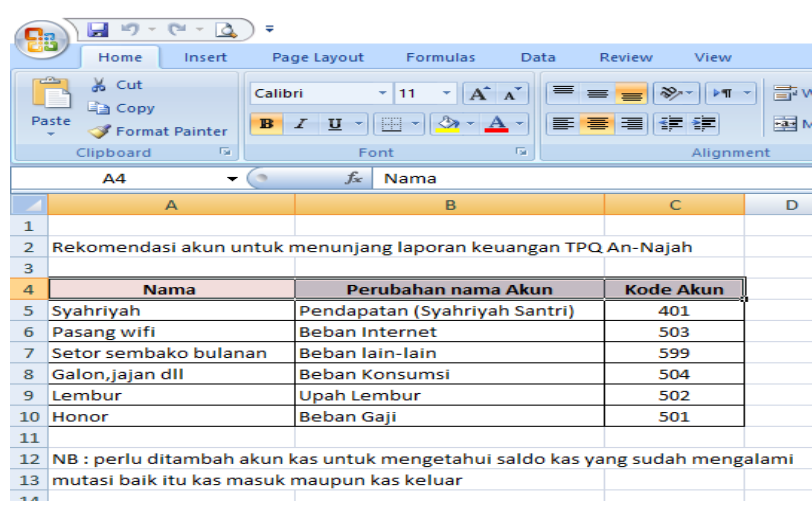

Gambar 2 Rekomendasi pengelompokan akun untuk laporan keuangan

Akuntansi sangat mengenal sekali saldo normal akun. Saldo normal akun adalah suatu ketetapan yang pasti dalam ilmu akuntansi terkait dengan posisi akun atau rekening yang menjadi prinsip pembukuan berpasangan (Pratiwi, 2012) . Ketetapan yang diatur antara lain :

Tabel 2 Saldo normal akun

\begin{tabular}{ccc}
\hline $\begin{array}{c}\text { Kelompok } \\
\text { Akun }\end{array}$ & Bertambah & Berkurang \\
\hline Harta & Debit & Kredit \\
Hutang & Kredit & Debit \\
Modal & Kredit & Debit \\
Pendapatan & Kredit & Debit \\
Beban & Debit & Kredit \\
\hline
\end{tabular}

3. Penjurnalan transaksi secara umum

Jurnal umum adalah catatan akuntansi yang digunakan untuk tempat melakukan pencatatan transaksi keuangan secara kronologis. TPQ An-Najah dalam hal ini belum sama sekali menyentuh apa yang namanya jurnal umum. Jurnal umum memiliki jurnal yang selalu berpasangan debit-kredit hal ini yang menjadi bahan pelatihan. 


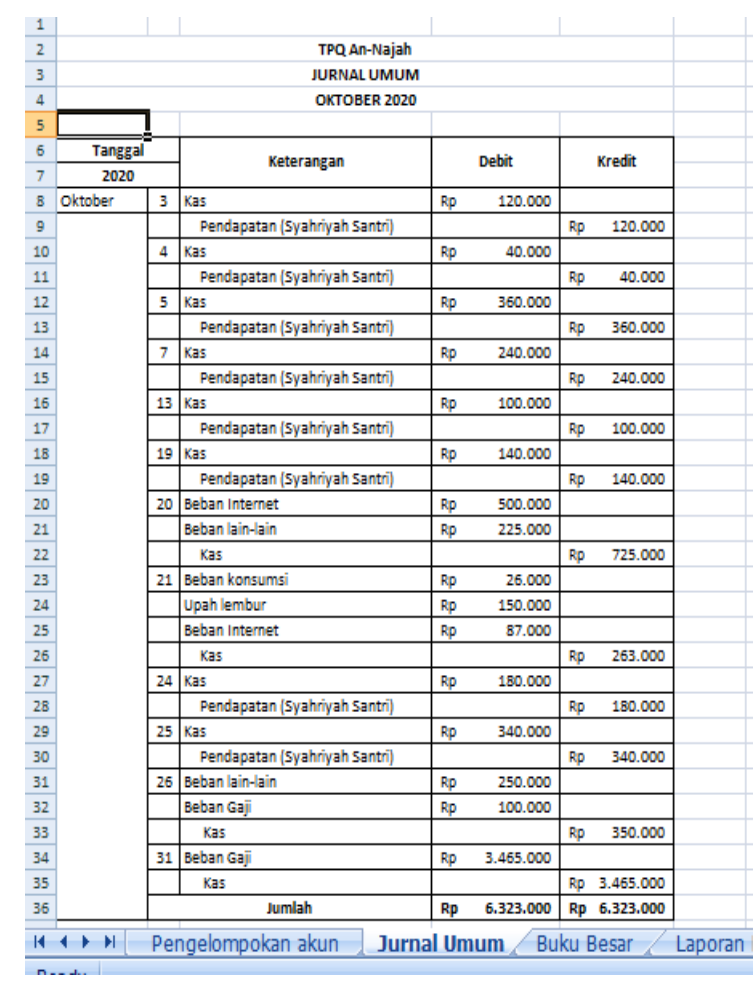

Gambar 3 Pelatihan membuat jurnal umum

\section{Posting Buku Besar}

Posting adalah proses pemindahbukuan informasi atau data akuntansi dari jurnal ke buku besar. Buku besar merupakan suatu alat atau buku yang digunakan sebagai tempat untuk perpindahan akun atau rekening yang berasal dari jurnal yang nantinya akan dipakai untuk membuat laporan keuangan. Intinya buku besar adalah sekumpulan dari berbagai akun/rekening/perkiraan yang dipakai untuk menyusun laporan keuangan.

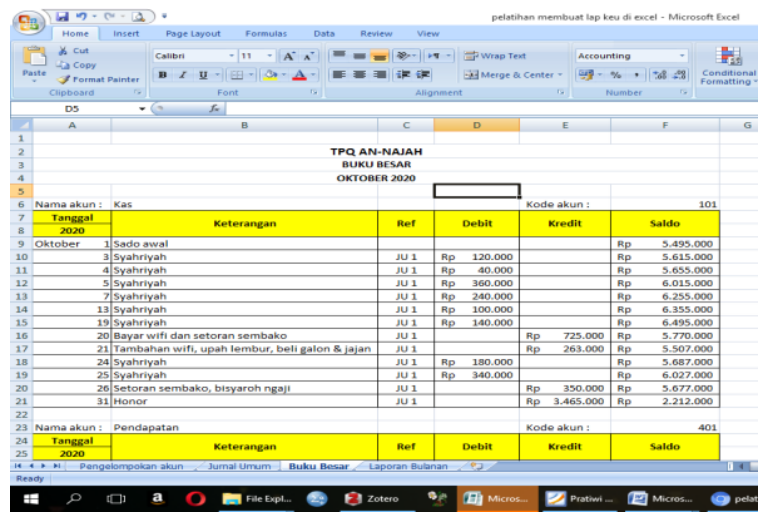

Gambar 4 Posting dari jurnal ke buku besar
5. Membuat laporan keuangan

Menurut Bastian laporan keuangan adalah hasil akhir dari proses akuntansi yang menyajikan informasi bagi berbagai pihak yang berkepentingan (Bastian, 2013). Apabila pencatatan setiap transaksi selama satu periode tertentu dalam hal ini per cawu (catur wulan) telah dilakukan maka langkah selanjutnya adalah menyusun laporan keuangan. Laporan keuangan dapat dibuat secara mingguan, bulanan, triwulanan atau tahunan. Namun, biasanya laporan keuangan minimal secara bulanan.

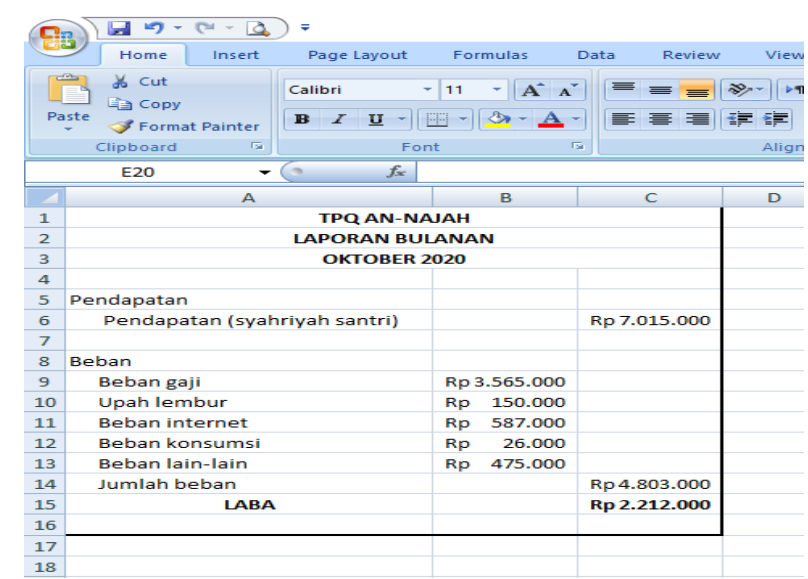

Gambar 5 Membuat laporan keuangan bulanan

\section{Penerapan Penggunaan Microsoft Excel Pada Laporan Keuangan TPQ An-Najah}

Microsoft Excel yang diterapkan disini, user hanya melakukan entry penjurnalan, buku besar laporan keuangan saja sebagaimana seperti software-software akuntansi lainnya. Dengan menggunakan rumus- rumus sheet satu dengan sheet lainnya, file satu dengan file lainnya menjadi berhubungan.

\section{Penggunaan Aplikasi Microsoft Excel Untuk Laporan Keuangan TPQ An-Najah}

Secara umum penggunaanya masih sama seperti sebelum diberi rumus-rumus dan masih mudah karena format-formatnya disesuaikan dengan yang sudah berjalan di TPQ. Hanya saja perlu pembiasaan dalam mengaplikasikannya karena jika hanya mengandalkan manualnya maka salah satu dampaknya adalah kurang efektifnya waktu. 
Kelebihan Sistem Informasi Akuntansi Berbasis Komputer Akuntansi khususnya Microsoft Excel.

Dari hasil pembahasan diatas ternyata Microsoft Excel mempunyai peranan yang penting dalam penyusunan sistem informasi akuntansi terhadap laporan keuangan. Jika suatu institusi masih melakukan sistem informasi akuntansi dalam proses manual bisa dibayangkan betapa rumit dan memakan banyak waktu. Proses pencatatan akuntansi yang bersifat manual memerlukan beberapa langkah atau tahapan dalam pengerjaannya. Selain itu kemampuan manusia yang terbatas jika bekerja melebih batas waktu dan tenaga yang dimilikinya. Maka ia akan mengalami gangguan mental seperti kondisi fisik yang tidak stabil, cepat lelah, lupa dan sebagainya. Dengan menggunakan software akuntansi maka sistem informasi akan menjadi lebih cepat. Begitu juga di TPQ An-Najah kecepatan dalam menghasilkan suatu laporan keuangan menjadi lebih cepat dan tingkat kesalahan semakin kecil. Berdasarkan uraian diatas penerapan Microsoft Excel dibandingkan dengan sistem lama yang digunakan dapat dilihat pada tabel 3 .

Tabel 3 Perbedaan menggunakan Microsoft Excel dan

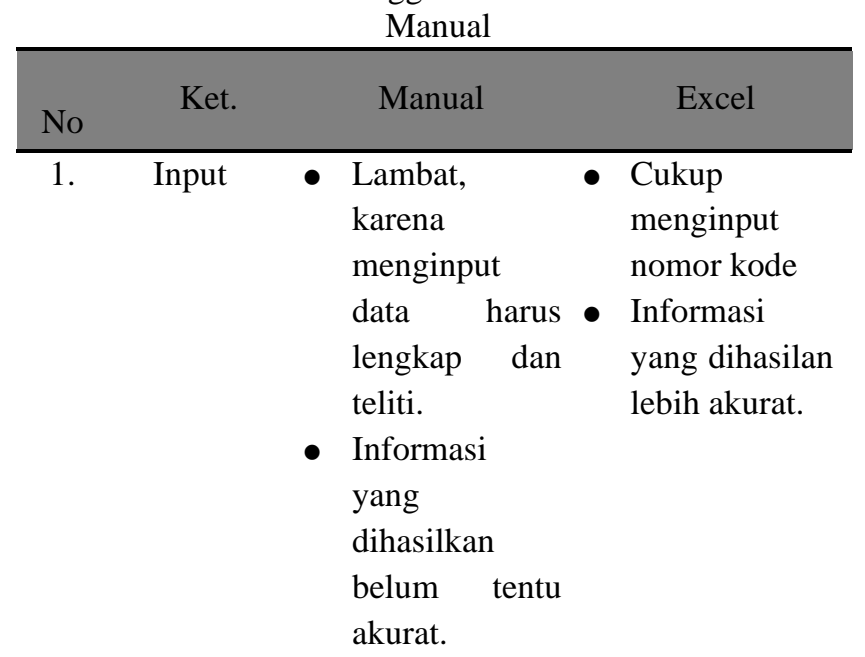

2. Proses Membutuhkan

$\begin{array}{lll}\text { banyak waktu, } & \text { dan singkat } \\ \text { biaya dan tenaga } & \text { - } & \text { Tingkat } \\ \text { dalam } & \text { terjadinya } \\ \text { mengerjakannya. } & \text { kesalah } \\ & \text { sedikit. }\end{array}$

3. Output Masih harus Kroscek tidak banyak di perlu berulangkroscek. ulang

\section{PENUTUP}

\section{Kesimpulan}

Laporan keuangan dalam pelaksanaannya sangat memegang peranan sebagai sumber informasi dan alat bantu dalam mengambil suatu keputusan, khususnya dalam memperoleh gambaran kondisi kinerja keuangan suatu lembaga apakah surplus atau defisit. Melalui catatan yang baik dan dilakukan secara konsisten serta periodik akan sangat membantu mengingatkan mengenai semua transaksi yang telah dilakukan. Catatan mengenai transaksi tersebut yang merupakan sumber utama pembuatan laporan keuangan.

Melalui penataan dan pembuatan laporan keuangan yang baik dan benar, diharapkan kelak TPQ An-Najah tidak akan mengalami kesulitan lagi ketika akan melakukan kerjasama dengan pihak luar. Untuk itu, penyusunan laporan keuangan perlu dilakukan secara berkesinambungan. Dalam hal ini lembar kerja elektronik Microsoft Excel sangat membantu dalam penyusunan laporan keuangan. Tentunya dengan format pencatatan sederhana seperti yang telah dijelaskan dalam tulisan ini dapat membantu pembaca dalam menyusun laporan keuangan secara sederhana.

\section{Saran}

Penelitian ini masih memiliki banyak kekurangan, oleh karenanya untuk penelitian selanjutnya diharapkan dapat lebih memberikan gambaran mengenai pengelompokkan akun, menjurnal dan posting buku besar serta penyusunan laporan keuangannya dapat dibuat dengan lebih detail.

\section{DAFTAR PUSTAKA}

Bastian, I., 2013. Sistem Akuntansi Sektor Publik, 3. Jakarta : Salemba Empat.

Daryanto, 2011. Administasi Pendidikan. Jakarta :PT Rineka Cipta

Hariani, P.P., Sihotang, I.M.M., 2020. Excel Mempermudah Penyusunan Laporan Keuangan. J. PRODIKMAS Has. Pengabdi. Kpd. Masy. 4, 50-57.

Horngren, C.T., 2011. Akuntansi Keuangan International Financial Reporting 
Standards-IFRS, Delapan Jilid 1. ed. Erlangga, Surabaya.

Ikatan Akuntan Indonesia, 2009. Standar Akuntansi Keuangan. Jakarta :Salemba Empat

Niati, A., Soelistiyono, A., Ariefiantoro, T., 2019. Pengembangan Kemampuan Sumber Daya Manusia melalui Pelatihan Komputer Microsoft Office Excel untuk Meningkatkan Kinerja Perangkat Desa Mranggen. E-Dimas J. Pengabdi. Kpd. Masy. 10, 105-110.

Nofiani, D., 2019. Administrasi Ketatausahaan Sekolah.

Pratiwi, R.D., 2012. Menyusun laporan keuangan sederhana dengan Microsoft excel. MEDIA 19.

Rohiat, 2012. Manajemen Sekolah. Bandung :PT Refika Aditama.

Rokhman, M.M., Adi Wibowo, S., Agus Pranoto, Y., Ardi Widodo, K., 2018. Pelatihan Pemanfaatan Microsoft Office Pada Staf Pengajar di SMPLBN (Sekolah Menengah Pertama Luar Biasa Negeri) Kota Malang. J. Mnemon. 1.

Supriyanto, 2016. Retrospektif Ilmu Administrasi Bisnis. Mitra Wacana Media, Jakarta.

Triandi, T., Agustin, M., 2016. Penggunaan Microsoft Excel Dalam Penyusunan Laporan Keuangan Untuk Meningkatkan Kualitas Informasi Laporan Keuangan. J. Ilm. Akunt. Kesatuan 4, 035-047.

Yudha, A., Marlina, T., Fahmi, A., 2017. Pelatihan Membuat Laporan Keuangan dengan Microsoft Excel BUMDes Pagelaran. J. Abdimas 1, 9-12. 